\title{
CURRENT STATE AND DEVELOPMENT OF SPECIALIZED ENTERPRISES - PRODUCERS OF SUNFLOWER
}

\begin{abstract}
This study is dedicated to the analysis of the current state and economic efficiency of agricultural enterprises engaged in the cultivation of sunflower. The auther stated the need for the development of this industry, its high potential in ensuring the profitable activities of agricultural producers and meeting the needs of the population. Using the grouping method allows to determine the most favorable conditions for profit making by specialized enterprises. As the result of the foundings in this article, were proposed the directions of further intensive development of this industry, as one of the leading in the structure of the agricultural sector of the country, which can satisfy the needs of domestic and foreign markets. The interest of agricultural producers in the cultivation of sunflower can be explained by its high profitability, as it was evidenced by the results of the calculations and official statistics. All data only confirms the conclusions about the high interest in the cultivation of sunflower by agricultural enterprises of Ukraine, which is the best motivator for the proposed actions for sunflower producers development.
\end{abstract}

Keywords: sunflower production, cost, profitability, economic efficiency.

\section{INTRODUCTION}

In Ukraine, sunflower occupies significant sown areas among industrial crops, which are mainly located in agricultural enterprises of the Steppe and Forest-Steppe. Sunflower farms in 19 regions and the Autonomous Republic of Crimea are grown, using mainly zoned varieties. Part of the sunflower seeds is exported, and Ukraine is one of the five world exporters.

In terms of the production of sunflower seeds in recent years, Ukraine is one of the first places in the world among the main exporters, and export is oriented both to raw materials and to finished vegetable oil. But the issues associated with expanding the production capacities of integrated processing of sunflower raw materials remain relevant, and they need to be worked out at the government level.

\section{THE OBJECT OF RESEARCH}

The author investigates the current state and prospects of production and processing of sunflower, as well as the importance of the industry for individual enterprises. It is

\footnotetext{
${ }^{1}$ Olena Cherednichenko, PhD, Department of Economics, Faculty of Economy, National University of Life and Environmental Sciences of Ukraine; e-mail: ya1971@ukr.net. ORCID: 0000-0001$-8908-4113$.
} 
important to note the need to develop this industry, both to achieve the main goal of agricultural producers, and to meet the needs of the population, as well as successfully solve the problems of this industry in certain regions of Ukraine.

\section{THE AIM AND OBJECTIVES OF RESEARCH}

The aim of the study is to consider the features and identify promising areas for the development of production and processing of sunflower by agricultural enterprises of Ukraine. The solution of the problems of state regulation and the further development of oilseed production has attracted and continues to attract the attention of many researchers: O.M. Ivanitskaya (Ivanitskaya, 2015), P.T. Sabluk (Sabluk, 2011), A.M. Shpichak (Shpichak, 2017), V.V. Yurchishin (Yurchishin, 2012) and others. In the studies, various aspects of the development of production and processing of sunflower in the agro-industrial complex of Ukraine were analyzed and recommendations for improving its efficiency were proposed. However, the development of this industry requires constant monitoring of problems with financial, innovative and other aspects that are not adequately covered in scientific research.

\section{METHODS OF RESEARCH}

The problem can be solved on the basis of the use of the dialectical method, as well as the application of the evolutionary approach - gradual development, which is based on continuous, gradual quantitative change. Economic-mathematical modeling is an effective tool for substantiation of perspective directions of development.

\section{RESEARCH RESULTS}

According to the author's concept of the approach, the implementation of promising directions for the development of production and processing of sunflower with the stimulating role of the state should be carried out simultaneously in all main areas:

- improvement of tax, credit, monetary, customs and tariff policies, investment policy in order to create and maintain mutually beneficial cooperation between the state and enterprises, to create the prerequisites for sustainable growth of the agricultural economy, protection of domestic producers and the domestic market;

- changing the role and forms of direct economic regulation with a view to more closely linking the interests of different levels and business entities;

- improvement of the legislative policy aimed at creating a single and more or less stable legal space.

In Ukraine, there are favorable natural conditions for the cultivation of sunflower. The main producers of sunflower seeds are in the Dnipropetrovsk, Donetsk, Zaporizhzhya, Kropyvnytsky, Lugansk and Kharkov regions, and provide $2 / 3$ of gross production. The high demand for sunflower and its processed products, as well as high profitability, make this crop very popular among agricultural producers, who are constantly increasing their sown area.

An analysis of the dynamics of sown areas, productivity and gross production of sunflower seeds suggests that the increase in production occurs due to the expansion of sown areas of the crop. For the period 1990-2000 the sown area has grown more than 1.7 times and reached 2842 thousand ha. During the same period, the yield of sunflower seeds 
decreased, and their gross production increased by $34.5 \%$ precisely due to the expansion of sown areas. The yield of oilseeds varied significantly depending on weather, climate and other conditions.

In 2000-2009 a 1.5 times increase in the sunflower sown area and predominantly positive dynamics of its productivity led to an increase in the gross production of sunflower seeds by more than 1.8 times. Sunflower is mainly grown by agricultural enterprises, but its production is also increasing in households. During 2005-2009 the population produced $21.2-31.8 \%$ of sunflower seeds, and their volume amounted to more than 2 million tons of seeds, while the share of agricultural enterprises decreased slightly.

In 2012-2018 an increase in the cultivated area of sunflower by $21.4 \%$ and predominantly positive dynamics of its productivity led to an increase in gross production of sunflower seeds by almost $70 \%$.

During 2012-2018 the population increased cultivated areas by $12.6 \%$, and the volume of production - by 57\%. Sunflower yields in households were stably lower - in 2018, $18 \mathrm{c} /$ ha versus $24.1 \mathrm{c} / \mathrm{ha}$ in agricultural enterprises. This indicates a more effective activity of agricultural enterprises, of great opportunities to adapt to the conditions and use the necessary material and technical base. The proportion of agricultural enterprises in the production of sunflower seeds continues to increase and reaches $86.1 \%$ (Table 1).

Table 1. Sunflower production in Ukraine

\begin{tabular}{|l|c|c|c|c|c|}
\hline \multicolumn{1}{|c|}{ Index } & $\mathbf{2 0 1 2}$ & $\mathbf{2 0 1 4}$ & $\mathbf{2 0 1 6}$ & $\mathbf{2 0 1 8}$ & $\mathbf{2 0 1 8}$ to 2012, \% \\
\hline Area, thousand ha & 5081,7 & 5212,2 & 6086,7 & 6166,5 & 121,4 \\
\hline including agricultural enterprises & 4106,6 & 4226 & 4981,4 & 5068,7 & 123,4 \\
\hline \% to the general category & 80,8 & 81,1 & 81,8 & 82,2 & X \\
\hline households & 975,1 & 986,2 & 1105,3 & 1097,8 & 112,6 \\
\hline Production, thousand tons & 8387 & 10134 & 13627 & 14165 & 168,9 \\
\hline including agricultural enterprises & 7131 & 8682 & 11730 & 12194 & 171,0 \\
\hline \% to the general category & 85,0 & 85,7 & 86,1 & 86,1 & X \\
\hline households & 1256 & 1452,1 & 1896,8 & 1971,6 & 157,0 \\
\hline Productivity, c/ha & 16,5 & 19,4 & 22,4 & 23,0 & 139,4 \\
\hline including agricultural enterprises & 17,4 & 20,5 & 23,5 & 24,1 & 138,5 \\
\hline \% to the general category & 105,2 & 105,7 & 105,2 & 104,8 & X \\
\hline households & 12,9 & 14,7 & 17,2 & 18,0 & 139,5 \\
\hline
\end{tabular}

Source: Bulletin of Statistical service of Ukraine (2019).

Now in Ukraine there is an excessive expansion of sunflower sowing areas, saturation of crop rotation by it is more than a scientifically based norm. Sunflower is sown even in those regions whose natural conditions do not meet the requirements of this crop, in particular in the farms of the arid zone of the southern Steppe, northern and western ForestSteppe, and in Polesie. In this regard, in the main region of sunflower production, the alternation of crops in the field crop rotation is disrupted, which is important for this crop, given the high level of absorption of nutrients and moisture from the soil, as well as susceptibility to diseases and pest damage when placing crops on that the same area.

But neither disturbance of crop rotation, nor an increase in the number of pests, nor the unpredictability of the weather force farmers to abandon the cultivation of crops. Due to the high liquidity of sunflower, agricultural enterprises aim to seek new methods of 
management. This is also evidenced by the dynamics of productivity: over the past 10 years, it has increased from $14.3 \mathrm{c} / \mathrm{ha}$ to $24 \mathrm{c} / \mathrm{ha}$.

Considering phytosanitary and agrotechnical requirements, the area of sunflower crops in the country should not be more than 1.6-1.7 million hectares, but today this figure is almost 4 times higher than scientifically based norms. This is explained by the forced reseeding of winter crops, market demand, and the desire of owners to improve the economic situation of farms. In addition, Ukraine's leading positions among countries that grow high-oleic sunflower, which is not inferior in quality to olive oil, growing demand, exceeding supply, and a sharp increase in prices stimulate agricultural producers to pay more and more attention to this crop.

The production of oilseeds is important in the economy of agricultural enterprises, farms and farms.

As a result of high economic efficiency, growth of demand and competitiveness in the market oilseeds are marked by the highest rates of increase in production in world agriculture. As a result, the area under crops and the yield of oilseeds are growing, the range of products is being improved, their role in the economy is increasing, and the volume of trade on the world market is increasing. As a general trend, the world is outpacing the production of vegetable fats compared to animal fats. The high value of oilseeds is determined by the fact that vegetable fats are the most valuable concentrated sources of energy.

Most agricultural enterprises are engaged in the sale of sunflower seeds, namely $65.4 \%$ of the total number of farms, but over the past period the number of enterprises selling sunflower has decreased by more than 250 .

Among all manufacturers, enterprises with a level of specialization of up to $30 \%$ predominate. Approximately the same number of enterprises have a level of specialization from $30 \%$ to $60 \%$, but they sold almost half of these products. Enterprises with a level of specialization of more than $60 \%$ of only $18.8 \%$ and a quarter of sales are provided by them.

The share of sunflower in the proceeds from the sale of agricultural products, respectively, the largest in farms with a level of specialization of more than $90 \%$ and is $96.7 \%$, and in farms with a level of specialization up to $30 \%$ - only $14 \%$.

215 agricultural enterprises in Ukraine have a level of specialization of more than $90 \%$, of which 129 are engaged only in sunflower cultivation. The average area of sunflower per farm is 653 hectares, and the yield is 24.2 centners per hectare. The largest average area of crops of 764 hectares falls on the second group of farms. The highest yields were achieved by enterprises with a level of specialization of more than $90 \%-27 \mathrm{c} / \mathrm{ha}$, and the lowest with a level of specialization from $30 \%$ to $60 \%-23.2 \mathrm{c} / \mathrm{ha}$. And these farms have the lowest production costs per 1 hectare.

The lowest cost of 1 quintal of sunflower was recorded in farms with a level of specialization of more than $90 \%$, and the highest selling price in farms with a level of specialization from $30 \%$ to $60 \%$. The best level of profitability of $65.2 \%$ was received by enterprises with a level of specialization from $60 \%$ to $90 \%$, and the lowest $-61.8 \%$ - by enterprises with a level of specialization up to $30 \%$.

Specialized farms for growing sunflower received the best indicators in the Odessa region (Cherednichenko, 2013). The lowest, compared with other regions, the total cost of 1 centner at $268 \mathrm{UAH}$ allowed enterprises at a low price of $746.22 \mathrm{UAH} / \mathrm{centner}$ to achieve a high level of profitability of $178.5 \%$. 
The smallest yield of $26.1 \mathrm{c} / \mathrm{ha}$ and a low level of profitability of $66.1 \%$ were recorded in enterprises of the Kropyvnytsky region. And, although these enterprises sold sunflower at the highest price, the highest production costs and high cost limited the ability to get high profits (Table 2).

Economic indicators of sunflower production in large and medium agricultural enterprises of Ukraine confirm the general situation in this area. For the period 2012-2018 there was an expansion of sown areas by $18.7 \%$ and an increase in productivity by $20 \%$, which ultimately led to an increase in sunflower production by $42.5 \%$ and its sales volume - by $28.3 \%$.

Table 2. Indicators of sunflower production in specialized agricultural enterprises by regions

\begin{tabular}{|l|c|c|c|c|}
\hline \multicolumn{1}{|c|}{ Index } & Kropyvnytsky & Odessa & Vinnytsia & Nikolaev \\
\hline Area, ha & 1774 & 2963 & 3260 & 1315 \\
\hline Production, centners & 46331 & 116085 & 107430 & 52200 \\
\hline Productivity, c/ha & 26,1 & 39,2 & 33,0 & 39,7 \\
\hline Production cost 1 centner, UAH & 411,73 & 259,69 & 289,61 & 236,33 \\
\hline Total cost 1 centner, UAH & 521,85 & 267,99 & 331,65 & 332,31 \\
\hline Price 1 centner, UAH & 866,67 & 746,22 & 845,60 & 854,68 \\
\hline Profitability, \% & 66,1 & 178,5 & 155,0 & 157,2 \\
\hline $\begin{array}{l}\text { The share of sunflower in revenue from } \\
\text { sales of agricultural production, \% }\end{array}$ & 100 & 100 & 96 & 100 \\
\hline
\end{tabular}

Source: Bulletin of Statistical service of Ukraine (2019).

A 3-fold increase in production costs led to a 2.5-fold increase in prime cost. An almost similar increase in the selling price did not save the situation, and as a result, the profitability level in 2018 was lower by 20 percentage points for the previous year and by 4.5 points than in 2012. At the same time, sales volumes of sunflower increased by $28 \%$, and the share of sunflower in the proceeds from the sale of agricultural products in these farms in recent years has remained at about $23 \%$.

In favor of sunflower producers, the fact of a constant increase in the capacity of domestic processors is triggered. Over the past 15 years, 37 new oil and fat enterprises have been built in Ukraine, and most of the existing ones have modernized their own production. Accordingly, it is possible to intensify competition in the domestic raw materials market through underutilization of capacities.

The leader among the largest sunflower processors is "Kernel", which produces about $23 \%$ of the volume of unrefined sunflower oil, $20 \%$ of refined oil, and $22 \%$ of sunflower meal/cake.

The top ten domestic producers of unrefined sunflower oil produce $48.7 \%$ of this type of product. The top five producers of unrefined sunflower oil also included the industrial group "Vioil" - 7\% of its total production, LLC "European Transport Stevedoring Company" of the company "Bunge" - 6.9\%, LLC "Optimus Agro" - 6.4\%, "Myronivsky Hliboproduct" $-6 \%$.

The TOP-10 producers of refined oil produce almost $80 \%$ of the domestic market. The largest companies - producers of refined sunflower oil after the company "Kernel" is the company "Bunge Ukraine", which produces $17 \%$ of its total production, and the group of companies "Delta Wilmar" - $14 \%$. 
The leader among domestic enterprises in this segment is PJSC with foreign investments "Dnipropetrovsk Oil Extraction Plant" of the company "Bunge", which covers $14.7 \%$ of the market of refined sunflower oil. The second is "Delta Wilmar CIS" LLC of "Delta Vilmar", which occupies $12.4 \%$ of the market, the third - PJSC "Poltava Oil Extraction Plant" of Kernel $-11.8 \%$ of the market for this type of product.

The leaders in the production of sunflower meal after the company "Kernel" are LLC "Optimus Agro" - 7\% of their total production and LLC "European Transport Stevedoring Company" of the company "Bunge" $-7 \%$.

$97.3 \%$ of the total volume of rapeseed oil in Ukraine is produced by 6 enterprises. The top three leaders include PJSC "Vinnytsia Oil and Fat Plant" of the industrial group "ViOil" with a share of $25.5 \%$, LLC "Olsid Black Sea" with a market share of $22 \%$ and LLC "Delta Wilmar CIS" of the company "Delta Wilmar" with a share market in $14.4 \%$

There are a number of problems in this area, one of which is the insufficient number of processing plants. The existing capacities of oil plants in Ukraine have been reloaded with processing of sunflower, soybean and rapeseed.

\section{CONCLUSIONS}

According to these factors, the prospects for the development of efficient production and processing of sunflower in the agro-industrial complex of Ukraine are as follows:

- reducing the cost of growing and processing sunflower, the use of the latest technologies to increase productivity and product quality and reduce the price for the end consumer;

- creation of innovative products for additional income of the producer, expansion of the range of consumers of different contingent groups and maximum satisfaction of their needs;

- the formation of agro-industrial clusters that would ensure a continuous technological process of production, starting with the cultivation of agricultural products, their processing, production and sale of products;

- attraction of foreign investments for expansion of product range, updating of material and technical base, modernization of production process, introduction of resourcesaving and low-waste productions and improvement of results of activity of enterprises;

- ensuring compliance with sanitary and phytosanitary standards; implementation of the HACCP food safety system and other certification systems; orientation of domestic producers not only to foreign markets but also to the domestic market, increasing the competitiveness of products at the global level;

- improvement of the national regulatory policy in the field of foreign trade relations in order to increase the competitiveness of exports, and to continue the protectionist policy towards domestic producers.

The interest of agricultural producers in the cultivation of sunflower can be explained by its high profitability, as evidenced by the results of the calculations and official statistics.

All data only confirms the conclusions about the high interest in the cultivation of sunflower by agricultural enterprises of Ukraine. And they testify to the further intensive development of this industry, as one of the leading in the structure of the country's agricultural sector, which can satisfy the needs of domestic and foreign markets. 


\section{REFERENCES}

Bulletin of Statistical service of Ukraine (2019). [online]. Access on the internet: available at: http://www.ukrstat.gov.ua/.

Cherednichenko, O.O. (2011). Features of effective functioning of oil and fat subcomplex. Bulletin of Sumy National Agrarian University. Series „Finance and Credit”, № 1.

Cherednichenko, O.O., Topalova, T.V. (2013). Economic efficiency of sunflower production and processing and ways to increase it in Artsyz district of Odessa region. Scientific Bulletin of NULES of Ukraine. Series: Economics, Agrarian Management, Business, (181-2).

Gerasymchuk, N.A., Mirzoeva, T.V. (2017). Economic effectiveness of sunflower production and main factors of its provisition at agricultural enterprises. Herald of the Kyiv National University of Technology and Design, № 3 (111).

Gerasymchuk, N.A. (2011). Competitiveness of the agricultural sector of Ukraine in the global food crisis. "Economy. Management. Innovation" (2).

Ivanitskaya, O.M. (2015). WTO role in regulating world trade in goods and services. International Economic Relations: [a Study Guide] Kyiv: NAU.

Sabluk, P.T. (2011). Agrarian sector of Ukraine: institutional principles of further transformations. Bulletin of Economic Science of Ukraine. № 2.

Shpichak, A.M. (2017). Purchasing, wholesale and retail prices for agricultural products and products of its processing (August 2016 - August 2017), Kyiv: NSC "IAE".

Yurchishin, V.V. (2012). Innovative aspects of the evolution of economic science. "Ekonomika APK” № 1.

DOI: $10.7862 /$ rz.2020.mmr.11

The text was submitted to the editorial office: May 2020.

The text was accepted for publication: June 2020. 
